\title{
Determinants of Household Decision to Join Community Forest Associations: A Case Study of Kenya
}

\author{
Josephine Kamene Musyoki, ${ }^{1}$ Jayne Mugwe, $^{2}$ Kennedy Mutundu, ${ }^{3}$ and Mbae Muchiri ${ }^{1}$ \\ ${ }^{1}$ Kenya Forestry Research Institute, P.O. Box 20412-00200, Nairobi, Kenya \\ ${ }^{2}$ Department of Agricultural Resource Management, Kenyatta University, P.O. Box 43844-00100, Nairobi, Kenya \\ ${ }^{3}$ School of Social Sciences, Mount Kenya University, P.O. Box 342-01000, Thika, Kenya \\ Correspondence should be addressed to Josephine Kamene Musyoki; josephinemusyoki@yahoo.com
}

Received 11 September 2012; Accepted 3 October 2012

Academic Editors: P. Newton and P. Smethurst

Copyright (C) 2013 Josephine Kamene Musyoki et al. This is an open access article distributed under the Creative Commons Attribution License, which permits unrestricted use, distribution, and reproduction in any medium, provided the original work is properly cited.

\begin{abstract}
Forests contribute significantly to the livelihoods of forest adjacent communities. Under the Kenya's new Forest Act (2005), community participation in forest conservation is provided for through formation of Community Forest Associations (CFAs). This study focused on Ontukigo and Ngare Ndare CFAs involved in participatory management of Ontulili and Ngare Ndare forests in North Central Kenya. It aimed at identifying household factors associated with decision to participate in PFM and the differences between CFA and non-CFA members in their participation in forest conservation activities. Semi structured questionnaires were administered to randomly selected 80 CFA and 80 non-CFA members. Factors influencing household decision to join CFA included household size $(t=2.065, P=0.05)$, age $(t=2.408, P=0.01)$, number of cows $(t=2.804, P=0.01)$ and $\operatorname{sheep}(t=1.656, P=0.01)$ owned by CFA (6.6) and non-CFA (4.2), farm size $(t=1.495, P=0.01)$ and forms of land tenure. Other factors included distance of homestead from forest $(t=-1.253, P=0.05)$, sources of fodder $\left(\chi^{2}=20.277, P=0.001\right)$, access to forest products $\left(\chi^{2}=15.882\right.$, $P=0.001)$, crop land $\left(\chi^{2}=22.762, P=0.001\right)$, and awareness of Forest Act $2005\left(\chi^{2}=22.227, P=0.001\right)$. Participation in forest conservation was positively influenced by CFA membership $\left(\chi^{2}=7.83, P=0.05\right)$. Majority of CFA members $(80 \%)$ participated highly in forest patrol, fire control, tree nurseries, and tree planting activities.
\end{abstract}

\section{Introduction}

Forests are globally important in conservation of the environment, biodiversity, water, and soil resources. Conservation of these resources is very vital because of their contribution to the livelihoods of communities living adjacent to the forest by providing them with various ecosystem goods and services. Some of the products obtained from the forests by adjacent communities include fuel wood, food in form of wild fruits and vegetables, medicinal herbs, wood for carving, and other small cottage industries. Other forest products accessed from the forests include dyes for adding value to handicrafts, honey, timber, poles, and posts, among others. Cultural services include use of forests as venues for traditional ceremonies such as circumcision and religious purposes [1].
In Kenya, gazetted forests cover a total area of 1.4 million hectares, representing about $1.7 \%$ of total land area. This does not meet the internationally recommended minimum of $10 \%$ of country forest cover. The forests outside gazetted forests are estimated to be 0.18 million hectares and are mainly situated in high and medium potential areas where the human population and agricultural production are concentrated [2].

There has been an increasing rate of forest destruction and consequential decline in forest resources in Kenya due to the high rate of increase in human population, thus exerting pressure on natural resources. The decline has been attributed to factors such as deforestation, commercial agriculture, urbanization, pastoralism, charcoal production, forest cultivation, and replacement of indigenous forests with exotic plantations [1]. Decline in forest resources has been further exacerbated by increasing poverty levels and the 
community perception of forest as a public good in addition to changing global forestry trends.

More so, weak capacity in forest institutions in conjunction with political obstruction, insufficient business environment, rigid budgetary allotments, and corrupt practices have also contributed to poor plantation management, abuse in the disposal of forest land and produce, and preferential licensing which have contributed to decline in supply of timber and other products [1]. Therefore, improving forest cover and reducing forest destruction and degradation have now surfaced as a significant element of Kenya' development strategy [3]. Central to this is the government' recognition of the critical role to be played by forest adjacent communities in ensuring that tree cover in the country is maintained above current alarming levels [4]. Conservation and management of natural resources have to actively involve all relevant stakeholders and particularly the local communities [5] for success.

The inclusion of communities in the management of state-owned forest resources has become increasingly common in the last 25 years. Schreckenberg et al. [6] indicated that majority of the countries in Africa and Asia are promoting the participation of rural communities in the management and utilization of natural forests and woodlands through some form of Participatory Forest Management (PFM). Participatory Forest Management is the local involvement of stakeholders in management of a forest, which may be dry woodlands, tropical forests, mangrove, or plantations, for the mutual benefit of both the species of flora and fauna and the community. In Kenya, it is a legal requirement according to the Forest Act 2005 that communities form Community Forest Associations (CFAs), before entering into a forest management agreement with Kenya Forest Service (KFS) under the PFM process [7].

In Kenya the formation of CFAs started in 1997, and currently there are over 40 forests where communities participate in forest management [8]. Studies have been undertaken on how major CFAs in Kenya such as ArabukoSokoke Forest Adjacent Dwellers Association (ASFADA) and Meru Forest Environmental and Protection Association (MEFECAP) operate and the challenges faced [9]. However, community perceptions on the capacity of the CFAs to meet PFM objectives and their perception on how to enhance the PFM process have not been assessed in forests in Timau region hence the need for this study.

The result and impacts of interventions in natural resource management in Kenya call for a clear understanding of how conservation goals can be reconciled with economic interests of local communities. This is because most of the rural households gain their livelihoods from natural resources. Natural resources in Kenya have continually been degraded due to the high discount rates of the local communities and a lack of clear policies that allow participatory management approaches. Participatory Forest Management approach therefore aims at improving forest cover and the livelihoods of forest adjacent communities as provided in the Forest Act 2005.

Studies on the emerging roles of CFAs in Kenya have presented the different challenges faced in implementing the PFM process [9]. Further examination of CFA roles in the decentralization process of Kenyan forests has highlighted the emerging issues which have slowed down the development of PFM process such as the right for communities to license extraction and movement of forest products, arrest and prosecution of offenders in forests under PFM, and cost and benefit sharing among others [10]. However, community perceptions on CFA capacity to meet PFM objectives and their views on these emerging issues have not been captured adequately. In addition, adequate understanding of the changing perceptions and attitudes of local communities towards PFM process is lacking. For example, we do not clearly understand the decision making of households in regard to joining CFA. Limited studies have been undertaken to identify factors influencing CFA members' level of participation in PFM and determinants of access to forest products in the two forest sites. Such information is crucial for sustained participation of CFA members and other community members in PFM. The missing information is needed in order to design forest management measures that will meet local needs and therefore attain long-term support for natural resource management initiatives [8].

Many researchers indicate the poorer people to be more dependent on natural resources. Therefore household socioeconomic characteristics may play a role in resource use decision making. Understanding factors influencing community participation in forest management programs such as PFM may be critical to forest managers and decision makers. Factors motivating their participation in decisions and activities for preservation of state forests or protected areas may be likewise important. A better understanding of community members' motivation for participation in PFM is fundamental to the development and implementation of management strategies that are both sustainable in the long term and sensitive to the local need [11]. Participation of rural community members in management of protected forests may vary according to socioeconomic and demographic backgrounds of the individual farmers. Individual community member's characteristics may influence decision making on whether or not to participate in PFM.

This study was therefore conducted with the aim of identifying household factors associated with decision to participate in community forest association and determining how CFA membership affects community members' participation in forest conservation in Ontulili and Ngare Ndare forests.

\section{Materials and Methods}

2.1. Study Area. This study was carried out in Ontukigo and Ngare Ndare CFAs operating in Ontulili and Ngare Ndare forests, respectively. These forests are located in Buuri District in Timau region curved from former larger Meru Central District in Kenya and it has two divisions, namely, Timau and Buuri.

Ngare Ndare forest covers an area of 5554.3 hectares $\left(54 \mathrm{~km}^{2}\right)$ and lies between $0^{\circ} 07^{\prime} \mathrm{N}$ to $0^{\circ} 10^{\prime} \mathrm{N}$ and $37^{\circ} 18^{\prime} \mathrm{E}$ to $37^{\circ} 27^{\prime} \mathrm{E}$. The forest is 2336 metres above sea level and $260 \mathrm{~km}$ from Nairobi through Nanyuki town. It is predominantly a 
dry cedar forest with an annual rainfall of about $450 \mathrm{~mm}$ occurring between March-May and November-December and average temperature is between $20^{\circ} \mathrm{C}$ and $28^{\circ} \mathrm{C}$ [12]. Villages covered in the household survey included Mbuju, Ngare Ndare, Suboiga, and Ethi.

Ontulili forest is located within latitude $0.0666667^{\circ}$ and longitude $07.2833333^{\circ}$, about $15 \mathrm{~km}$ from Nanyuki town on the way to Meru, and is wetter than Ngare Ndare forest. Villages surveyed around Ontulili where forest include Katheri, Lower Ngusishi, Upper Ngusishi, and Sirimon.

These forests are part of the seven forests formerly referred to as Mt Kenya forests and they are located near Mt. Kenya National Park. The study was undertaken in Ontulili and Ngare Ndare forest stations because the two forests are part of Mount Kenya Forest, which is one of the 5 key water towers in Kenya and many people depend on it for their livelihoods. Moreover, the two forests have different climatic and management conditions with the former being a wet forest under plantation management and the latter being relatively drier and under indigenous vegetation. Ontukigo CFA and Ngare Ndare CFA have both embraced PFM undertaking different activities.

2.2. Target Population and Sample Size. Purposive sampling technique was used to select CFAs working in the two forest sites due to their longterm PFM experience in this study area. Focused group discussions were held in each of the forest site with at least 10 members drawn randomly from the CFAs and non-CFA members adjacent to these forests to provide the needed information. Interview schedules were administered to KFS staff, KWS, CFA staff, and other stakeholders' officials selected by use of snowball sampling method [13].

For household interviews, the respondents were selected by use of stratified random sampling method whereby stratification was based on CFA membership. This was to ensure that CFA and non-CFA members were well represented during the survey. Gay [14] proposes that for correlation research, 30 cases or more are required. Therefore based on this premise, the semistructured questionnaire was administered to 80 CFA and 80 Non-CFA members selected by stratified random procedure from at least 4 randomly selected villages surrounding each of the two forests. Eighty households were interviewed around each forest site giving a total of 160 households in both Ontulili and Ngare Ndare forest stations.

2.3. Data Collection Methods and Instruments. Secondary data were obtained through review of relevant literature from libraries and Internet including resource materials such as journals, annual reports, books, workshop proceedings, periodicals, PFM reports, and district reports. Primary data was obtained by use of various qualitative and quantitative methods. The objectives of this study were mainly achieved by use of semi-structured household survey. The household survey data was complemented through application of different PRA tools.

Household factors associated with decision to participate in community forest association were identified through household interviews done using structured questionnaires administered to selected households of both CFA and nonCFA members. Socioeconomic information from a crosssection of these households was obtained to gain an understanding of variations between families. CFA and non-CFA members not represented among the leaders or focused group discussion had an opportunity to air their views concerning the PFM process. It also provided the opportunity to compare community-wide issues discussed during community meetings with household level conditions [15]. Factors such as gender, household size, farm size, homestead distance from the forest, and numbers of livestock owned, among other factors, were analyzed comparatively for both CFA and non-CFA members. This helped to identify the significant factors associated with the decision to join CFA and participate in PFM. Differences between CFA and non-CFA members in their level of participation in forest conservation activities were attained using semi-structured questionnaires.

2.4. Data Analysis. This study generated both qualitative data from PRA tools and quantitative data from semi-structured questionnaires administered through household surveys. The qualitative data obtained through PRA tools were subjected to in-depth analysis and used to complement the discussion of analysed quantitative data. The quantitative data were cleaned, sorted, summarized, and stored using MS Excel. The data was presented in forms of charts and tables where necessary.

Chi-square test statistics $\left(\chi^{2}\right)$ were computed for quantitative data using SPSS 17 to assess association between categorical variables. Computation of Chi-square values from the data was done as per the formula below:

$$
\chi^{2}=\sum_{i}\left[\frac{\left(n_{i}-E_{i}\right)^{2}}{E_{i}}\right],
$$

where, $n_{i}=$ the observed number in category $i$ and $E_{i}$ is the expected number under Ho (Null Hypothesis). Rejection region: reject Ho if $\chi^{2}$ exceeds the tabulated critical value for $P$ ranging between 0.05 and 0.001 and Degrees of Freedom (df) $=k-1$, where $k$ is the total number of categories [16].

Spearman rank order correlation statistic $\left(r_{s}\right)$ measures the monotonic association between variables $x$ and $y$. It is used to determine whether $y$ increases (or decreases) with $x$, even when the relation between $x$ and $y$ is not necessarily linear. For the data in this report $r_{s}$ was used determine the relationship between household size and fuel wood consumption, age and number of trees, and farm size and number of trees. For comparison of average farm size, number of livestock, trees, mean age, and number of trees planted by CFA and non-CFA members, $t$-test for independent samples was used to test whether the difference between the means was significant or not [16].

\section{Results and Discussion}

\subsection{Factors Influencing Household Decision to Join CFA}

3.1.1. Gender and Household Headship. The relationship between CFA membership and gender had some significance 
hence gender is an important determinant in household decision to join CFA $\left(\chi^{2}=3.79, P=0.05\right)$. More so, gender had a significant influence on participation of community members in forest conservation irrespective of CFA member$\operatorname{ship}\left(\chi^{2}=4.215, P=0.04\right)$. This agrees with the observation made by Coulibaly-Lingani et al. [17] in Burkina Faso, that there is a highly significant relation between gender and participation in forest conservation. This implies that gender is important in forest participation in Kenya as for other developing countries such as Burkina Faso. Male and female community members experience different circumstances that affect their participation in forest conservation activities such as fire fighting and forest patrol, among other activities. Women's personal and household attributes constrain their participation in community organizations in Southern Burkina Faso. Women are quite disadvantaged due to their social and household chores such as childcare, fetching water, cooking, and farming. Their role hinders them sparing time from domestic chores to participate in conservation activities or attend forest management meetings [18]. In both Ontulili and Ngare Ndare forests, there is no significant association between CFA membership and nature of household headship $\left(\chi^{2}=1.02, P=0.08\right)$, hence decision to join CFA is not necessarily determined by household headship.

3.1.2. Household Sizes. The households surveyed in both sites had a total of 849 household members out of whom $54.1 \%$ were members of CFA households and $45.9 \%$ were members of non-CFA households. There was a significant difference ( $t$-test where $t=2.065, P=0.05)$ between the household size of CFA members (mean $=5.7$ members per family) and non-CFA members (Mean $=4.8$ members per family). Hence, household size is an important determinant of household decision to join CFA. It is most likely that CFA members have a greater demand for forest products such as firewood due to their larger household sizes hence the decision to join CFA in order to increase their chances of accessing forest products. This agrees with the observations of Chhetri [19] that households with large family size are in better position to utilize the community forest resources and hence are likely to participate more in PFM to meet their needs for forest products. Similarly, Dolisca et al. [11] in a case study from Haiti identified household size to have a positive effect on social level participation in forest management. This indicates that households with fewer members are less likely to participate in social forestry activities. Coulibaly-Lingani et al. [17] also noted in a related study that respondents' household size had a positive effect on participation in decision making. This meant that heads of large families are more interested in participating in forest management decision making process than other community members. This is also attributed to the possibility that individuals with larger families depend on forest resources to diversify household livelihoods as they may find it challenging to access alternative sources of livelihood [20].

3.1.3. Ages of CFA and Non-CFA Members. The mean ages of CFA (46 years) were significantly different from those of nonCFA members (41 years) in both forests $(t=2.408, P=0.01)$.
Therefore, age could be an important determinant factor in household decision to participate in PFM probably because the two communities respect the decision of the aged. This shows that more aged people were more interested in joining CFA than the younger people who have various commitments that they value more than participating in PFM activities through joining CFA. The older may also be interested because they have time to participate and due to the fact that they value their forests and are interested in conserving them. At the age of 46 years, most of the community members have families whom they have to fend for; hence they depend on the forest to meet their domestic needs for forest products. They are also within the active age band at which they can participate in forest conservation activities in addition to having a better chance to access various forest products. Highest participation in forest conservation for all community members in the two study sites was noted for respondents within the age band of 35-50 years. Other studies have reported conflicting results in regard to the influence of age on participation in forestry activities. For instance, Thacher et al. [21] and Zhang and Flick [22] found age to have no influence on forest management while Dolisca et al. [11] found that age had a negative impact in explaining the level of participation in forestry activities. This implies that the young people were willing to participate in forest activities unlike in this study where the older people were the major participants through CFA.

\subsubsection{Level of Education of Forest Adjacent Communities.} Most (42.5\%) of the CFA members in Ngare Ndare had a secondary school level of education while for Ontukigo CFA, most members had upper primary level of education. In both sites most of the non-CFA members had upper primary level of education. There was no significant association between the level of education and CFA membership in each of the forest sites. There was also no relationship between level of education and level of participation of both CFA and non-CFA members in forest conservation and their access to various forest products such as firewood, herbs, and fodder and thatch grass, among others. These results agree with the results of Coulibaly-Lingani et al. [20] that education did not influence respondent's access to the forest for fuel wood extraction and grazing livestock. However, previous studies show that education level has a tendency to reduce forest dependency. A higher level of education provides a wider range of job options, hence making fuel wood collection unprofitable due to greater opportunity costs of collection [23].

Contrary to the findings of Obua et al. [24] that education tends to increase one's awareness of the importance of the environment and of natural resources, in this study, there was no relationship between level of education of both CFA and non-CFA members and their awareness of the Forest Act 2005, growing of trees, and participation in forest conservation.

3.1.5. Distance of Homesteads from the Forests. There was a significant difference between the average CFA and nonCFA homestead distances from the forests $(t=-1.253, P=$ $0.05)$. Therefore, homestead distance is a determinant factor 
in household decision to join CFA in both forest sites. Considering the relationship between general participation of all community members in forest conservation irrespective of CFA membership, it was also noted that range of homestead distance from the forest had a very significant influence on the number of community members participating in forest conservation $\left(\chi^{2}=20.686, P<0.001\right)$. As the distance of homestead from the forest increased, the number of community members participating in forest conservation activities decreased. Highest number of those participating (61\%) was within $0-1 \mathrm{~km}$ distances, reduced to $32.9 \%(1.1-3 \mathrm{~km})$, $4.8 \%(3.1-5 \mathrm{~km})$, and reduced further down to $1.4 \%$ (over $5.1 \mathrm{~km}$ ). This result concurs with Chhetri's [19] observation that distance of the forest from the household had significant inverse relationship with participation in forest management.

3.1.6. Landholdings for CFA and Non-CFA Members. The difference between the average farm sizes for CFA (3.484 acres) and non-CFA members (2.306 acres) was significant $(t=1.495, P=0.01)$. CFA members had larger farms available for their use probably because they had more interest in growing crops and had more livestock, hence forcing them to buy more land or rent as well as being able to access government forest land for grazing and for cultivation under PELIS in Ontulili forest. Being accessible to more land could also be a contribution of PFM to improved well-being of the CFA members.

Land Tenure for CFA and Non-CFA Members. The main types of land tenure were, privately owned land with title deed, government forest allocated land, squatters, and rented farms. All the Ngare Ndare CFA members interviewed had title deeds compared to $90 \%$ of the Ontukigo CFA members interviewed. In Ontulili forest site, there were 15\% of the CFA members who had government land allocated to them by KFS mainly for use under PELIS. This is a system through which the CFA members are allowed to cultivate small parcels of land on the condition that they prepare the land for tree planting, participate in tree nursery establishment and tree planting activities within the forest, while tending the planted tree seedlings to enhance their survival.

The CFAs had accessed their land through purchase (45\%), inheritance $(27.5 \%)$, free allocation $(27.5 \%)$, and through allocation by KFS (15\%). The non-CFA had accessed their land through purchase (45\%), inheritance (32.5\%), and free allocation $(22.5 \%)$. It was noted that renting of land as a form of land tenure influenced CFA membership negatively $\left(\chi^{2}=8.421, P=0.003\right.$, Gamma value $\left.=-1.000\right)$. This form of land tenure also had a negative influence on growing of trees on farm $\left(\chi^{2}=16.916, P<0.001\right.$, Gamma value $=$ $-0.921)$ and access to forest products and services $\left(\chi^{2}=\right.$ 14.902, $P=0.002$, Gamma value $=-0.842)$. Government forestland allocation influenced CFA membership positively $\left(\chi^{2}=12.973, P<0.001\right.$, Gamma value $\left.=1.000\right)$. Having title deed for land as a form of tenure had positive influence on tree growing in the farms $\left(\chi^{2}=19.537, P<0.001\right.$, Gamma value $=0.852$ ) on access to forest products and services $\left(\chi^{2}=6.109, P=0.02\right.$, Gamma value $\left.=0.616\right)$. This finding is consistent with the findings of Zhang and Pearse [25], which indicated that land tenure influences farmers' motivation to participate in forest management activities. Land tenure forms with longer terms and those being secure and able to provide more benefits to their holders were more likely to encourage participation in reforestation. It was similarly observed by Dolischa et al. [11] that lack of secure land rights had contributed to farmer's nonparticipation in forestry programs in Haiti.

3.1.7. Crop Land for CFA and Non-CFA Members. Majority of the community members living adjacent to Ngare Ndare forest and Ontulili forest depend on cash crop as source of livelihood. Majority of the community members plant both cash crops and food crops in their own farms. In Ngare Ndare forest, there was no association between CFA membership and place where crops are grown since none of the community members grow crops in the forest irrespective of their CFA membership status.

In Ontulili forest, there is a highly significant association between CFA membership and place where crops were grown $\left(\chi^{2}=22.762, P=0.001\right)$. This is because the few community members growing crops in Ontulili forest under PELIS system are CFA members only. Therefore in Ontulili, place where crops are grown was an important determinant in household decision to join CFA.

3.1.8. Livestock Production and Sources of Fodder. CFA members owned majority of the livestock in both forest sites. Types of livestock owned include cows, goats, and sheep. This is possibly the reason why it is the majority of CFA members who were using the government forests as source of fodder compared to the non-CFA members. There were 75 CFA members owning livestock; out of whom 68 CFA members owned cows, 21 owned goats, and 26 owned sheep. Out of 62 non-CFA members having livestock, 49 of them owned cows, 12 owned goats, and 27 owned sheep. There was significant difference between the mean number of cows ( $t=2.804, P=0.005)$ kept by CFA (3.2) and non-CFA (2.2) as well as the mean number of sheep $(t=1.656, P=$ 0.01 ) owned by CFA (6.8) and non-CFA (4.2). Hence number of livestock was an important determinant in household decision to join CFA. This could be more attributed to increased access of CFA members to government forest for fodder and grazing. Similarly, Chhetri [19] observed that households with more livestock were more inclined to use community forest resources for their higher demand for fodder and ground grass. Adhikari et al. reported [23] that households who keep more livestock are benefiting more from the community forests.

Majority of CFA and non-CFA members having livestock had their own farms and government forest as the major sources of fodder. Therefore, it is important to enhance fodder production in both government forests and on farms to ensure sustainable supply. There was significant association between CFA membership and sources of fodder $\left(\chi^{2}=\right.$ 20.277, $P=0.001)$. More CFA members were in need of 
fodder than the non-CFA members because CFAs had more livestock than non-CFA.

3.1.9. Access to Forest Products. Most community members $(85 \%)$ involved in this study indicated that they have access to forest products from the adjacent forest irrespective of CFA membership. However, a higher percentage of the CFAs members had access to forest products and services from the adjacent forests compared to non-CFA members.

There was a positive strong relationship between CFA membership and access to forest products and services $($ Gamma $=0.803)$ and the association was highly significant $\left(\chi^{2}=15.882, P=0.001\right)$. This implies that joining CFA enhanced the community members' access to forest products, implying that PFM conferred high access to CFA members than non-CFA members. It was similarly noted in Nepal that households involved in various decision-making activities collected more fuel wood. This was attributed to the information acquired through various forms of community meetings concerning when to collect and where to collect firewood from the forest [23].

Temesgen [26] noted that unless communities access forest resources to support their livelihoods, the pressure will rise to breaking point and further forest destruction will follow. Therefore sustainable forest management is enhanced when communities are provided with clear and recognized access rights to the forest resources. It also calls for multistakeholder agreements on the objectives of the forest management including increased though sustainable use of existing nontimber forest products from the forest.

3.1.10. Awareness of Forest Act 2005. There was a significant positive relationship between CFA membership and awareness about the provision for community participation in forest management by the Forest Act 2005 in both Ontulili and Ngare Ndare forest sites $\left(\chi^{2}=22.227, P=0.001\right)$. This implies that awareness about the forest Act 2005 is an important determinant for household decision to join CFA.

The main sources of information on the forest Act 2005 and the provision for community participation in forest management were outlined as CFA officials and KFS staff. There was a highly significant association between CFA membership and the major sources of information, that is, CFA officials $\left(\chi^{2}=19.867, P=0.001\right)$ and KFS staff $\left(\chi^{2}=19.297, P=0.001\right)$. Therefore as community members joined CFA, they increased their chances of interaction with CFA officials and KFS staff, hence enhancing their access to information about the forest Act 2005 and the PFM process.

\subsection{Differences between CFA and Non-CFA Members in Forest Conservation}

3.2.1. Participation of CFA and Non-CFA Members in Forest Conservation. The community members living adjacent to both Ontulili and Ngare Ndare forests indicated that they participated in various forest conservation activities irrespective of whether they were CFA members or not. It was observed that $97.5 \%$ of the CFA members were participating in forest conservation activities compared to $85 \%$ of the non-CFA.

There was a positive significant association between CFA membership and participation in forest conservation $\left(\chi^{2}=\right.$ $7.83, P=0.05$, Gamma value $=0.746)$. This has an implication that for more participation of community members in forest conservation activities, the government through KFS should mobilize the community members to join CFA in each of these forests. The number of CFA and non-CFA members participating in forest conservation varied from one type of activity to another. Analysis of those community members participating in each forest conservation activity revealed that there were a greater percentage of CFA members participating in each forest conservation activity as compared to the non-CFA members.

There was a strong positive relationship between CFA membership and participation in the major forest conservation activities in both Ontulili and Ngare Ndare forests. These activities include forest patrol $\left(\chi^{2}=18.83\right.$, $P=0.001$, Gamma value $=0.674)$, tree planting $\left(\chi^{2}=56.29\right.$, $P=0.001$, Gamma value $=0.886)$, fire fighting $\left(\chi^{2}=76.79\right.$, $P=0.001$, Gamma value $=0.961)$, and tree nursery activities $\left(\chi^{2}=117.44, P=0.001\right.$, Gamma value $\left.=0.996\right)$. Therefore CFA membership encourages more participation in forest conservation than non-CFA membership. This agrees with the observations made by Pretty and Smith [27] that social capital is an important resource for shaping individual's participation in biodiversity conservation. Therefore CFA membership seems to strengthen the social capital of the community members living adjacent to the two study forests with a goal of improving forest management while improving their livelihood. Social capital includes characteristics of social organizations such as networks, norms, and trust that enable participants to act together more effectively in order to pursue shared objectives (Putman [28]) and this is apparent in the two CFAs studied. In Haiti, Dolisca et al. [11] noted that respondents who indicated membership to local groups were positive towards social, environmental, and economic participation inside Forêt des Pins Reserve. This is attributed to the possibility that non-local group members are not well informed about forestry programmes hence may overvalue or underestimate the benefits.

\subsubsection{CFA Membership and Training on Forest Management} and Conservation. One of the expected benefits of joining PFM or living adjacent to a forest where PFM is in practice is training in forest management and other aspects related to sustainable land use and agriculture. Training influences the level of participation in forest conservation activities and depending on the type of training provided, it enhances participation in specific PFM activities, such as, tree planting and tree nursery establishment and management, among other activities.

In this study, community participation in forest conservation was not influenced by education level but was positively influenced by training in forest management $\left(\chi^{2}=10.572\right.$, $P=0.001$, Gamma $=1.000)$. The positive influence of training on CFA participation in forest conservation agrees 
with the observation that knowledge about forest conservation issues makes people more positive in their views [29]. Salam et al. [30] also noted that community members often lack the appropriate technologies needed in management of participatory forestry through which they can maximize the potential of sustainable forest development. Training on various aspects of PFM is needed to successfully undertake PFM activities. Salam proposed that training manuals based on field experiences and incorporating knowledge possessed by the local people should be provided. Training on different aspects of PFM was positively related to sustained participation of community members. Improving and updating the skills and knowledge in PFM can encourage community members to involve themselves in sustained participation.

Lack of sufficient knowledge of forest management has been mentioned as a reason for local community members' unwillingness to participate in forest management [24]; hence in the two areas this was sorted out through training. When considering factors that affect people's participation in PFM in Oromia region, Degeti and Yemshaw [31] also found out that awareness creation contributed to the understanding of the importance of forests, hence encouraging community members to participate in forest management actively. Having a better Knowledge about the social and economic impact of deforestation encourages people to take part in forest management actively. Training is one of the best ways to create awareness.

A strong positive association between CFA membership and training in forest management and other land use related aspects was observed (Gamma value $=0.820$ ) and the association was highly significant $\left(\chi^{2}=41.264, P=\right.$ $0.001)$. Training is therefore influenced positively by CFA membership; hence joining CFA under the PFM process provides the community members with greater opportunities for training. Training does not only help the community members manage the forest appropriately and hence increase forest cover but it also provides the appropriate environment for farmers to exchange views on better agricultural production technologies and issues related to other income generating activities. Training motivates farmers to adopt and adapt new technologies.

3.2.3. Community Members' Involvement in On-Farm Tree Growing Activities. Both CFAs and non-CFAs were involved in tree planting in their farms as indicated by $74.4 \%$ of the 160 community members in both Ontulili and Ngare Ndare forest sites. Growing trees on farm by both CFA and non-CFA members was positively influenced by their participation in forest conservation activities $\left(\chi^{2}=7.997, P=0.005\right)$. Among the 119 community members growing trees in their farms, 95\% of them were those participating in forest conservation. There were no significant differences in on-farm tree planting in the two sites. Out of the respondents growing trees, 52.9\% of them were those living adjacent to Ontulili forest and $47.1 \%$ of them were those living adjacent to Ngare Ndare forest.

There was a significant association between CFA membership and planting of trees on farm $\left(\chi^{2}=3.97, P=\right.$
0.05). More CFA members (81.3\%) than non-CFA members $(67.5 \%)$ had planted trees in their farms. It was also noted that training of CFA members in forest related aspects influenced growing of trees positively $\left(\chi^{2}=7.652, P=\right.$ 0.006 , Gamma value $=0.693$ ). Therefore, majority of CFAs growing trees had been trained in tree planting and tree nursery establishment under PFM. The CFA members had free access to seedlings from their group nurseries for onfarm planting thus enhancing their adoption of on-farm tree planting practices.

\section{Conclusion and Recommendations}

4.1. Conclusion. The first objective of this study was to identify household factors associated with the decision of households to join Community Forest Associations in Ontulili and Ngare Ndare forests. The study hypothesized factors such as gender, household size, nature of household head, age, level of education of household heads, well-being categories of households, distance of homesteads from forest, land holdings/farm sizes, and crop land to influence decision to join CFA. Factors found to be significantly associated with household decision to join CFA were household size, age, possession of animals, farm size, access to forest products, awareness about PFM under new Forest Act, and access to training in forest management aspects. CFA members were found to have significantly larger household sizes than nonCFA. The average ages for CFA and Non-CFA members were 46 and 41 years, respectively, and their difference was significant. Therefore age of household heads positively determines the household decision to join CFA with likelihood of more aged households joining CFA than the younger ones.

Most of the community members had title deed for their farms and $15 \%$ of the Ontukigo CFA respondents were cultivating in the government forest allocated to them by KFS under PELIS. The major and alternative sources of livelihood for community members in both sites were cash crop growing and livestock keeping, respectively. The CFA members owned most of the livestock in both forest sites. Majority of CFA and non-CFA members having livestock had their own farms and government forest as the major sources of fodder. There was significant relationship between CFA membership and sources of fodder and the average number of cows and average number of sheep for the CFA and non-CFA members. Therefore number of livestock and sources of fodder are important determinants in household decision to join CFA.

Majority of Ngare Ndare CFA members had secondary school level of education while majority of the non-CFA had upper primary level of education. In Ontulili, majority of both the CFA members and non-CFA had upper primary level of education. However, there was no significant relationship between CFA membership and the level of education. Majority of the CFA members in both sites were categorized as in "rich" and "poor" well-being categories. In Ngare Ndare, there was only one non-CFA member in very rich category and none of both CFA and non-CFA members was in the "very poor" well-being category.

The CFA and non-CFA members had differences in their level of participation in forest conservation activities. 
CFA members were found to participate more than nonCFA in forest conservation activities. There were more CFA members (97.5\%) participating in forest conservation activities than the non-CFA members (85\%). A significant relationship between CFA membership and participation in forest conservation was identified. More so, there was also a significant association between CFA membership and access to information on the Forest Act 2005 which provides for community participation in forest conservation and management. There was also a significant relationship between CFA membership and access to the major sources of information on the Forest Act 2005, that is, CFA officials and KFS staff. Community members' participation in PFM through joining CFA increased their opportunities for interaction with CFA officials and KFS staff, hence motivating them to participate in forest conservation activities. There was a significant relationship between CFA membership and participation in forest patrol, tree planting, fire fighting, and tree nursery activities. This implies that joining CFA encouraged participation in such activities. There was a significant relationship between respondents' awareness of forest conservation activities as CFA operations and their actual participation of CFA members in those identified activities such as tree nursery activities, tree planting, and forest patrol. However, participation in fire fighting was by all the CFA members irrespective of whether they recognized this activity as one of their CFA operations or not. This is because fires in the forest are emergencies that call for the attention of all CFA members who recognize the forest as an important resource for the community members.

There were more of the Ontukigo CFA members participating in forest patrol, tree planting, and tree nurseries than Ngare Ndare CFA members. PELIS is not practiced in Ngare Ndare forest. Very few of Ngare Ndare CFA members were participating in PFM training. Ontukigo CFA members provided labor directly for PFM activities such as tree nursery establishment and tree planting activities, forest patrol, and tree pruning and thinning while Ngare Ndare CFA employed community scouts to undertake patrol and other community members to plant trees in the forest.

Training was influenced positively by CFA membership, hence joining CFA under the PFM process provided the community members with greater opportunities for training. The main types of training accessed by the CFA members include tree planting and management, tree nursery establishment, training on the PFM process and group organization. Training in forest conservation and management was identified as one of the factors contributing to high level participation of CFA members in forest patrol (50.7\%), fire control $(71.6 \%)$, tree nursery activities (70.1\%), and tree planting (44.8\%). Planting of trees on the farms is positively influenced by training and the CFA membership status.

4.2. Recommendations. Based on this study of CFA and nonCFA members living adjacent to Ontulili and Ngare Ndare forest sites in Timau region, the following recommendations are considered to be vital in enhancing PFM.

(i) In promoting formation of CFAs, the government should seek ways of encouraging the participation of the youth to enhance sustainability in implementation of PFM activities. They should also focus on households with a great number of members and livestock especially cows and sheep. This is because household sizes and number of livestock are associated with household decision to join CFA. Creating awareness about the new forest Act and its PFM requirement was important in encouraging households to join CFA, hence needs to be prioritized at the initial stages of CFA formation and in new PFM sites.

(ii) CFA membership is associated with more participation in forest conservation and management. Therefore joining CFA as an institution encourages community members living adjacent to the forests to participate in forest conservation activities in the government forests. The government through KFS and other stakeholders should therefore mobilize community members living adjacent to forests to form such institutions for more participation in forest management.

(iii) The government should train community members in forest management and other sustainable land use practices to encourage on-farm tree planting and general participation in forest management activities.

(iv) Secure land tenure has to be ensured among community members for sustainable participation and support of PFM activities in new sites.

\section{Abbreviations}

ARPIP: Action Research into Poverty Impact of Participatory Forest Management

CBO: Community Based Organizations

CETRAD: Centre for Training and Research and Development

CFAs: Community Forest Associations

CIFOR: Centre for International Forestry Research

FAC: $\quad$ Forest adjacent communities

FAN: $\quad$ Forest Action Network

FAO: $\quad$ Food and Agriculture Organization of the United Nations

FGD: $\quad$ Focussed group discussion

IGAs: Income generating activities

KEFRI: Kenya Forestry Research Institute

KFS: Kenya Forest Service

KNBS: Kenya National Bureau of Statistics

NGO: Nongovernmental organizations

PELIS: Plantation establishment and livelihood improvement system

PFM: $\quad$ Participatory Forest Management

URT: United Republic of Tanzania

DRSRs: Department of Resource Surveys and

Remote Sensing

KFWG: Kenya Forests Working Group

MENR: Ministry of Environment and Natural Resources 
EMPAFORM: Strengthening and Empowering Civil Society for Implementation of Participatory Forest Management in East Africa

PRA: $\quad$ Participatory rural appraisal

IFAD: International forestry and agriculture development

SPSS: $\quad$ Statistical Package for Social Sciences.

\section{Acknowledgments}

The authors are highly indebted to Kenya Forestry Research Institute for financial support provided through the Dry Land National Programme and to Kenyatta University for their institutional support during this study. They also thank the Kenya Forest Service Officers in charge of Ontulili and Ngare Ndare forests, the Kenya wildlife Service staff, and the two Community Forest Associations for their cooperation.

\section{References}

[1] S. Geller, R. McConnell, and J. Wanyiri, "Linking national forest programmes and poverty reduction strategies, Kenya," Food and Agriculture Organization, Forestry Department, Forestry Policy and Institutions Service, 2007, http://www fao.org/forestry.

[2] A. Ruotsalainen, "Kenya forest master plan. Recognition of local forest users," in Seminar Reports and Journal of a Field Excursion to Kenya, P. Pellikka, J. Ylhaisi, and B. Clark, Eds., vol. 40, pp. 21-25, Expedition Reports of the Department of Geography, University of Helsinki, 2004.

[3] Department of Resource Surveys and Remote Sensing and Kenya Forests Working Group, Changes in Forest Cover in Kenya's Five Water Towers, 2003-2005, DRSRS and KWFG, 2006.

[4] Ministry of Environment and Natural Resources, "Sessional Paper no. 1 of 2007 on Forest Policy," Tech. Rep., Government Printer, Nairobi. Kenya, 2007.

[5] H. Purnomo, G. A. Mendoza, and R. Prabhu, "Analysis of local perspectives on sustainable forest management: an Indonesian case study," Journal of Environmental Management, vol. 74, no. 2, pp. 111-126, 2005.

[6] K. Schreckenberg, C. Luttrell, and C. Moss, Participatory Forest Management: An Overview, Forest Policy and Environment Programme, Grey Literature, UK, 2006.

[7] J. V. Ludeki, G. M. Wamukoya, and D. Walubengo, Environmental Management in Kenya: A Framework for Sustainable Forest Management in Kenya, Understanding the Draft Forest Policy and Forests Act 2005, 2006.

[8] T. Thenya, B. Wandago, and E. T. Nahama, "Participatory forest management experience in Kenya (1996-2006)," in Proceedings of the 1st National Participatory Forest Management Conference, KEFRI Headquarters, Nairobi, Kenya, 2007.

[9] P. O. Ongugo, M. T. E. Mbuvi, E. Obonyo et al., "Emerging roles of Community Forest Associations in Kenya: the cases of Arabuko-Sokoke Forest adjacent Dwellers Associations (ASFADA) and Meru Forest Environmental and Protection Community Association (MEFECAP)," in Proceedings of International conference on Poverty Reduction and Forests, Bangkok, Thailand, September 2007.
[10] P. O. Ongugo, J. N. Mogoi, E. Obonyo, and V. O. Oeba, "Examining the roles of Community Forest Associations in the decentralization process of Kenyan forest," in Proceedings of the International Association for the Study of Commons Conference, July 2008.

[11] F. Dolisca, D. R. Carter, J. M. McDaniel, D. A. Shannon, and C. M. Jolly, "Factors influencing farmers' participation in forestry management programs: a case study from Haiti," Forest Ecology and Management, vol. 236, no. 2-3, pp. 324-331, 2006.

[12] Ngare Ndare Forest Trust, Ngare Ndare Forest Management Plan, 2008-2013, Kenya forest Service and Kenya forest Working Group, Nairobi, Kenya, 2008.

[13] O. M. Mugenda and A. G. Mugenda, Research Methods: Qualitative and Quantitative Approaches, African Centre for Technology Studies, Nairobi, Kenya, 1999.

[14] L. R. Gay, Education Research: Competencies for Analysis and Application, Charles E. Mairill, A. Bell and Howell, London, UK, 1981.

[15] F. K. Lelo, J. O. Ayieko, R. N. Muhia et al., Egerton PRA Field Guide Book for Participatory Rural Appraisa Practitioners, PRA programme, Egerton University, Njoro, Kenya, 2000.

[16] R. L. Ott, An Introduction to Statistical Methods and Data Analysis, Wadsworth Publishing, Calif, USA, 4th edition, 1993.

[17] P. Coulibaly-Lingani, P. Savadogo, M. Tigabu, and P. C. Oden, "Factors influencing people's participation in the forest management program in Burkina Faso, West Africa," Forest Policy and Economics, vol. 13, no. 4, pp. 292-302, 2011.

[18] R. K. Nuggehalli and L. S. Prokopy, "Motivating factors and facilitating conditions explaining women's participation in comanagement of Sri Lankan forests," Forest Policy and Economics, vol. 11, no. 4, pp. 288-293, 2009.

[19] K. B. Chhetri, Community forestry program in the hills of Nepal: determinants of user participation and household dependency [M.S. thesis], Management of Natural Resources and Sustainable Agriculture, Norwegian University of Life Sciences, 2005.

[20] P. Coulibaly-Lingani, M. Tigabu, P. Savadogo, P. C. Oden, and J. M. Ouadba, "Determinants of access to forest products in southern Burkina Faso," Forest Policy and Economics, vol. 11, no. 7, pp. 516-524, 2009.

[21] T. Thacher, D. R. Lee, and J. W. Schelhas, "Farmer participation in reforestation incentive programs in Costa Rica," Agroforestry Systems, vol. 35, no. 3, pp. 269-289, 1996.

[22] D. Zhang and W. A. Flick, "Sticks, carrots, and reforestations investment," Land Economics, vol. 77, no. 3, pp. 453-456, 2001.

[23] B. Adhikari, S. Di Falco, and J. C. Lovett, "Household characteristics and forest dependency: evidence from common property forest management in Nepal," Ecological Economics, vol. 48, no. 2, pp. 245-257, 2004.

[24] J. Obua, A. Y. Banana, and N. Turyahabwe, "Attitudes of local communities towards forest management practices in Uganda: the case of Budongo forest reserve," Commonwealth Forestry Review, vol. 77, no. 2, pp. 113-118, 1998.

[25] D. Zhang and P. H. Pearse, "Differences in silvicultural investment under various types of forest tenure in British Columbia," Forest Science, vol. 42, no. 4, pp. 442-449, 1996.

[26] Z. Temesgen, B. Irwin, G. Jordan, and J. McKee, "Forest, use them or lose them, an argument for promoting forest-based livelihoods rather than alternative Non forest Based Livelihoods with PFM programme," in Proceedings of the International of Conference Participatory Forest Management (PFM), Biodiversity in Africa, E. Kelbessa and C. De Stoop, Eds., Addis Ababa, Ethiopia, March 2007. 
[27] J. Pretty and D. Smith, "Social capital in biodiversity conservation and management," Conservation Biology, vol. 18, no. 3, pp. 631-638, 2004.

[28] R. D. Putman, "The prosperous community: social capital and public life," American Prospect, vol. 13, pp. 35-42, 1993.

[29] J. T. Heinen, "Human behavior, incentives, protected area management," Conservation Biology, vol. 10, no. 2, pp. 681-684, 1996.

[30] M. A. Salam, T. Noguchi, and M. Koike, "Factors influencing the sustained participation of farmers in participatory forestry: a case study in central Sal forests in Bangladesh," Journal of Environmental Management, vol. 74, no. 1, pp. 43-51, 2005.

[31] T. Degeti and Y. Yemshaw, Factors affecting people's participation in participatory porest management: the case of IFMP Adaba-Dodola in Bale Zone of Oromia region [Master of Arts thesis], Arts in Regional and Local Development Studies (RLDS), School of Graduate Studies of Addis Ababa University, 2003. 

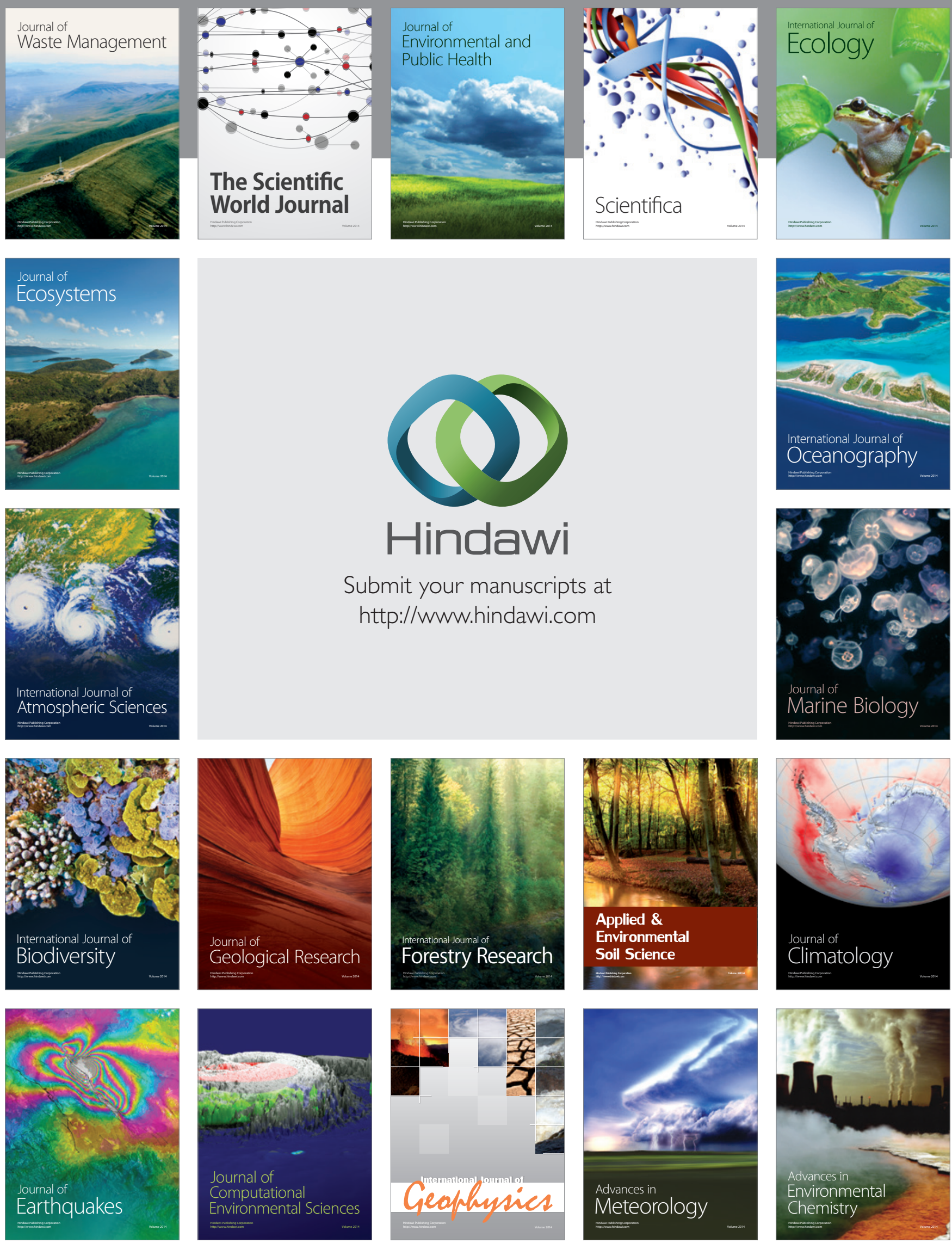